\title{
A note on bare-passives in (selected) Bantu and Western Nilotic Languages*
}

\author{
Fatima Hamlaoui
}

ZAS, Berlin

In the present paper, we concentrate on (selected) Bantu and Nilotic bare-passive strategies and lay out the basis for a typology of transitive passive constructions in these languages. We argue that bare-passives constitute an optimal strategy to change prominence relations between arguments, in languages that strongly hold to the default mapping between the highest thematic role available and the grammatical subject (i.e. Spec,TP). The Nilotic and Bantu languages discussed here differ in their way of satisfying this default mapping. In particular, impersonal bare-passives satisfy it by resorting to an agentive place-holder (an indefinite subject marker) and realizing the logical agent as a lower thematic/semantic role (e.g. instrument or locative). Left-dislocation and so called 'subjectobject' reversal bare-passives realize the default matching between agent and subject in a more straightforward way, but locate the patient in a higher argument position within the inflectional domain (Spec,TopP). As argued in Hamlaoui and Makasso (2013) and Hamlaoui (2013), and in line with Noonan (1977), the present languages display a clauseinternal split between subjecthood (being the grammatical subject in Spec,TP) and topicality (being the subject of the predication, in an inflectional-domain internal Spec,TopP).

\section{Introduction}

Passive forms are generally taken to express a change in argument relations (Shibatani, 1988). They display morphological or syntactic marking that indicates that the default mapping between subject/agent and non-agent/non-subject is not observed (in languages in which this is of course the default mapping) (Keenan and Dryer, 2007). From an information-structural perspective, passive sentences are often viewed as making the patient the "topic" of the sentence

* Many thanks go to Robert van Valin for first drawing our attention to Lango. We are grateful to the participants of the BantuSynPhonIS Workshop for their stimulating comments and questions, and in particular to Lutz Marten and Jenneke van der Wal for discussion and feedback on two manuscripts (Hamlaoui and Makasso, 2013; Hamlaoui, 2013) that were circulated in summer 2013. All remaining errors are our own. 
and thus as indicating that the agent is not. In languages in which there is a requirement for aligning foci with the right edge of the clause, passive structures can additionally achieve this goal for agents. Or, alternatively, they can also be a way of leaving out a discourse-given, unspecified or voluntarily-left-anonymous agent.

'Bare-passives', 'pseudo-passives' or 'zero-coded passives' are a crosslinguistically common phenomenon. They have been reported in a growing number of languages, stemming from various language families. They consist in sentences that 'fulfill all or most criteria for being called a passive but one: morphological or periphrastic marking of the verb phrase' (Cobbinah and Lüpke, 2009).

In the present paper, we concentrate on (selected) Bantu and Nilotic barepassive strategies and lay out the basis for a typology of transitive passive constructions in these languages. Interestingly, Bantu languages are characterized by their rich verbal morphology. Some of the languages discussed in the present paper actually have a passive morpheme and thus depart from the ones discussed by Cobbinah \& Lüpke, for which 'the absence of morphological marking for the passive is in line with the general paucity of morphological categories' (p154).

We propose that bare-passives constitute an optimal strategy to change prominence relations between arguments, in languages that strongly hold to the default mapping between the highest thematic role available and the grammatical subject (i.e. Spec,TP). In other words, bare passives allow to pragmatically and/or syntactically promote a non-agent argument, without departing from this default mapping. We contend that the Nilotic and Bantu languages discussed here differ in how they satisfy it. In particular, impersonal bare-passives (Section 2) resort to an agentive place-holder (an indefinite subject marker) and realize the logical agent as a lower thematic role (e.g. instrument or locative). Left-dislocation (Section 3) and so called 'subject-object' reversal bare-passives (Section 4) realize the default matching between agent and grammatical subject in a more straightforward way, but locate the patient in a higher argument position within the inflectional domain. So, as argued in Hamlaoui and Makasso (2013) and in line with Noonan (1977), the Bantu and Nilotic languages discussed in this paper display a clause-internal split between subjecthood (being the grammatical subject in Spec,TP) and topicality (being the subject of the predication). Together, they provide evidence for an inflectional-domain internal topic position right above TP, which hosts syntactically promoted objects in all three types of bare-passives discussed. In addition, this projection attracts the verb in the Kinyarwanda/Kirundi-type of OVS, which, we argue, is meant to align focused subjects with the right edge of the clause. Contrary to previous accounts according to which this type of OVS is derived by leaving the subject in Spec, $v \mathrm{P} / \mathrm{VP}$ or adjoining it to VP (see references infra), in our account, this 
order is derived by the verb and object simply moving higher than the position normally hosting subjects, i.e. Spec,TP. We conclude this note (Section 5) with a few typological remarks.

Before tackling the issue of bare-passives, let us however first introduce the type of languages that are discussed in the present paper. All five languages have SVO as their canonical word order, where S realizes the argument with the highest thematic/semantic role (we will here limit our discussion to agents). By default, the first nominal argument (linearly speaking) is understood as the most topical argument. In simple canonical sentences and all-focus contexts, the agent is thus simultaneously the grammatical subject and the topic. The pseudo-passive sentences discussed in the remainder of this paper emerge whenever another argument of the verb is more topical than the agent. We will not provide a full Optimal Theoretic account (Prince and Smolensky, 2004) in the present paper, but we take it that the constraint given in (1) (Zerbian (2007, 342), following Gundel $(1988,229)$ ) plays a crucial role, as the different structures discussed subsequently are also meant to optimally satisfy it.

(1) First Things First Principle

'Provide the most important information first.' [where "most important" should be understood as the most topical nominal phrase]

Whereas a number of SVO languages can satisfy this constraint by realizing a non-agent argument as the grammatical subject (i.e. in regular long passives), this is not the case in the Bantu and Nilotic languages discussed here. We believe that what the present languages have in common is that the agentivity of the grammatical subject (Spec,TP) is more important than its topicality.

\section{Impersonal passives}

Impersonal sentences are commonly found across languages. They display "an unspecified human agent which is also the subject of the sentence" (Frajzyingier, 1982). In the (standard) French sentence in (2), this unspecified human agent is expressed by means of a dedicated impersonal pronoun, on.

(2) En effet, on construisit le premier tabernacle, dans lequel était In effect INDEF.PRO built the first tabernacle in which was le chandelier, la table, et les pains de proposition; et il était appelé the candlestick the table and the breads of propositions and it was called le lieu saint. (Hébreux 9:2-3) the holy place

'For there was a tabernacle prepared, the first, wherein [were] the candlestick, and the table, and the showbread; which is called the Holy place.' (Hebrews 9:2-3, American Standard Version)

'For a tent was prepared, the first section, in which were the lampstand 
and the table and the bread of the Presence. It is called the Holy place.' (Hebrews 9:2-3, English Standard Version)

'They pitched the first tent called the holy place. It contained the lampstand, the table, and the loaves of bread presented to God.' (Hebrews 9:2-3, Common English Bible)

As shown by the different translations given in (2), there are several means to express the unspecified nature of an agent. A number of Bantu languages have been reported to use the class 2 subject marker, that is, a 3rd person plural marker. This is the case in Bàsàá, in (3), and in Mbuun, in (4). In the former case, the object occupies its canonical postverbal position, whereas in the latter case, it is preposed. ${ }^{1}$

6á-ḿ-má á ón 6ôm.

SM2-PST1-finish construct 7-market

'They finished constructing the market.' (Hamlaoui and Makasso, 2013)

(4) m-báa bá-é-dzim-i.

9-fire SM2-OM2-extinguish-PERF

'The fire has been extinguished (by someone)'

(Bostoen and Mundeke, 2011)

The impersonal structures that are of particular interest to us here, and which we call "impersonal passives" are those which, in addition to an unspecified agent marker, display what looks like an oblique agent. This type of impersonal passive, which is not found in French, Bàsàa or Mbuun, is briefly illustrated with (5) and (6) for Bantu (Bemba and Lunda, respectively) and in (7) for Nilotic (Dholuo). In all three languages, the patient can either precede or follow the verb. We will come back to the issue of object preposing in the following. Note that neither the agent, nor the patient determine the noun class of the subject marker (class 2 in Bantu and $\{-0-\}$ (perfect) $/\{-\mathrm{i}\}$ (imperfect) in Dholuo).

umw-áàna bá-alí-mu-ít-a ku mu-mbúlu. 1-child SM2-PAST-OM1-call-FV by 3-wild.dog 'This child was called by the wild dog.' (Kula and Marten, 2010)
nyi-kabu a-a-yi-nat-a
kúdi a-tu-ánsi.
4-fruit
SM2-PST-OM4-throw-fv by
2-13-child
'The fruits were thrown by the children.' (Kawasha, 2007, 39)

1 Abbreviations: AGR: agreement, CONN: connective, EXPL: expletive, FV: final vowel (Bantu), IMPERF: imperfective, INDEF: indefinite marker, lit: literally, NEG: negation, OM: object marker (Bantu), pl: plural, PASS: passive, PERF: perfective, PRES: present, PRO: prnoun, PST: past, REL: relative marker, sg: singular, SM: subject marker (Bantu, the number indicates nominal class) 
Whereas Dholuo does not have a passive marker, Bemba (M42, Zambia) does $(\{-\mathrm{w}-\})$, and thus casts doubt on the idea that the use of bare-passive strategies is caused by the paucity of morphological categories. Interestingly, long passives are 'judged ungrammatical or degraded' in Bemba. This is illustrated in (8).
a. úmu-náni u-alí-ípík-w-a.
3-food SM3-PST-cook-PASS-fv
'The food was cooked.'
b. ?? úmu-náni u-alí-ípík-w-a kulí Mutalé. 3-food SM3-PST-cook-PASS-fv by 1.Mutale
'The food was cooked by Mutale.' (Kula and Marten, 2010)

Kula and Marten $(2010,126)$ (henceforth $K \& M)$ note that, in contrast, long passives are acceptable with instruments, as illustrated in (9).
úmu-náni w-alí-ípík-w-a na supuuni.
3-food SM3-PST-cook-PASS-fv with 9.spoon
'The food was cooked with a spoon.'

These facts are consistent with the idea that bare-passive strategies find their source in the strong requirement for the selected argument with the highest thematic/semantic role to realize the grammatical subject. The underlying structure of sentences (5) to (7) however remains a controversial topic. ${ }^{2}$ In particular, researchers disagree on whether or not to analyze them as structural passive sentences, in which what we have been referring to as an unspecified agent marker should be treated as a passive-voice marker. Depending on the type of underlying structure associated with these sentences, one can draw different generalizations as to the existing types of natural languages.

By way of illustration, Cable (2012), who views Dholuo impersonal passives as structural passives, argues that this Nilotic language provides clear evidence for the existence of natural languages in which the preverbal subject position of a tensed verb can optionally be left empty. Indeed, if the sentences in (5) to (7) are structural passives in which the patient is the grammatical subject of the verb, it is noteworthy that this subject does not obligatorily occupy the preverbal, subject position, but can remain postverbal. Bantu impersonal passives have also been treated as structural passive sentences (Givón (1979), Haspelmath (1990) and to some extent Kula and Marten (2010)). In this approach, the

2 This controversy is reflected e.g. in how authors vary in their glossing of Dholuo verbs. Whereas Cable and Okoth-Okombo use a PASs(ive) gloss, Ochola uses EXPL(etive) and Tucker talks about an impersonal subject prefix. We generally only minimally adapted the original glossing of the examples for reasons of uniformity. 
fronted patient is considered to be the grammatical subject and the class 2 prefix a possible passive marker

In contrast, if the sentences in (5) to (7) are structurally active, impersonal sentences, and only functionally equivalent to passives, we believe that they show that there exists languages in which the grammatical subject position can only be filled by the highest thematic/semantic argument selected by a verb. ${ }^{3}$

\subsection{On the oblique-agent}

One of the main arguments in favor of the structural passive treatment of sentences of the type in (5) to (7) is the presence of the oblique-agent. According to the theta-criterion given in (10), the role of agent cannot be assigned twice, i.e. once to the indefinite pronoun and once to the oblique agent.

(10) 'Each argument bears one and only one $\theta$-role, and each $\theta$-role is assigned to one and only one argument.' (Chomsky, 1981, 35)

Note however that in the impersonal passive sentences we have reviewed so far, the oblique-agent is expressed either as a locative or an instrument. It seems worth considering that the co-occurrence of an indefinite subject pronoun and the instrumental/locative oblique-agent does not (at least on a certain level) violate the theta-criterion. We will not address the syntactic representation of impersonal passives in the present note. We hope to address it in future work.

In the case of Bemba, K\&M indicate, referring to Schadeberg $(2003,79)$, that the prepositions $k u$ and $k u l i$, which introduce Bemba oblique agents, probably stem from the class 17 locative concord $\mathrm{ku}$ - and the copula $\mathrm{li}$.

As for Dholuo, Tucker (436, fn. 8) mentions that although the prepositions $g i / k o^{\prime} d$ normally introduce an instrument, the young generation, "perhaps under the influence of Swahili and/or English", sometimes use it to introduce an agent. This is the case in the example (11). The possibility of expressing an oblique agent seems to be dependent on the age of the speaker (Siewierska, 2010). With the possibility of the demotion of an agent from subject to oblique, we might be witnessing a transitional stage in the Dholuo grammar: a reanalysis from impersonal-pseudo-passive to structural-passive. This however remains to be shown.

tát-wá-nó íruyo-nga gí yáwúót ló’ ká.

'Our roof is normally carried by the young men from the other side (of the river). [Tucker's fn. 8]

As noted by an anonymous reviewer for Hamlaoui (2013), this does not necessarily contradict Cable's claim if it can be shown that the Bantu class 2 subject marker and its Nilotic counterparts do not occupy the subject position but e.g. attach to the verbal complex. More research is necessary on this topic. 
To us, Tucker's observation suggests that the Dholuo impersonal passive might have evolved from a regular impersonal structure, with an unidentified or irrelevant agent (hence the use of an indefinite pronoun, just like in French, Bàsàá and Mbuun) in a (not so long ago) former stage of the language. The St. Joseph Society's grammar (1921) corroborates this view, by suggesting that in the presence of an identified agent, the basic SVO order used to be favored (over all possible alternative orders and despite the agent's lesser topicality). In the same footnote, Tucker adds the following: "But a sentence of the type 'our goat has been eaten by a hyena' is normally expressed 'diénd-wá óndíek oca-mo' lit 'Our goat a hyena has eaten'." This indicates that (at least some) Dholuo speakers (also?) have at their disposal bare-passive left-dislocation (see Section 3.2.).

Note in passing that the motivation for the clause-final location of the agent needs to be investigated. Interestingly, Okoth-Okombo $(1997,4)$ translates the following impersonal passive as a cleft-sentence, suggesting that in Dholuo, the clause-final agent is focused.
mon matiin ikendo gi jochan.
women rel.few INDEF.marry by people.of.poverty
'Few women are married by the poor.'
(It is the poor who marry few women)

We will see in Section 3.2., in connection to Bàsàá, that the use of bare-passive strategies is not necessarily related to agent-focusing.

\subsection{On subjects and objects}

A number of facts seem hardly compatible with the structural passive analysis and suggest a different approach to impersonal passives that we will make explicit below. First, in Dholuo, subjects of active verbs do not occur postverbally. This is also the case for unaccusative verbs. This is illustrated in (13) and (14). If a subject's movement to the preverbal position is optional in passive sentences, it is unclear why it is not also optional in active sentences.
a. Ochieng' ne ok oneno Onyango.
Ochieng' PAST NEG saw Onyango
'Ochieng didn't see Onyango.' [Cable's (7)]
b. $\quad \mathrm{Ne}$ ok oneno $\left({ }^{*}\right.$ Ochieng $\left.^{\prime}\right)$ Onyango $\left({ }^{*}\right.$ Ochieng $\left.{ }^{\prime}\right)$
PAST NEG saw Ochieng' Onyango Ochieng'
'Ochieng' didn't see Onyango.' [Cable's (14)]

(14) Ot wang' (*ot).

house burn house

'The house is burning.' [Cable's (16b)] 
Second, and this is particularly visible in the morphologically rich Bantu languages, the patient does not control subject-agreement, no matter whether it is pre or postverbal (Kula and Marten, 2010). This is illustrated in (15). This pattern is quite unexpected if the preverbal patient actually realizes the grammatical subject of the verb.
a. bá-alí-poos-a ífy-ákulya (ku bá-àna). SM2-PST-throw-FV 7-food by 2-children
'The food was thrown away by the children.'
b. ífy-ákulya bá-alí-poos-a (ku bá-àna).
7-food SM2-PST-throw-FV by 2-children
'The food was thrown away by the children.'

Third, and this is also visible in Bemba: fronted patients trigger object marking on the verb (Kula and Marten, 2010). This is visible with animate objects, as in (16).

$$
\begin{aligned}
& \text { umw-áàna bá-alí-mu-ít-a ku mu-mbúlu. } \\
& \text { 1-child SM2-PST-OM1-call-fv by 3-wild.dog } \\
& \text { 'The child was called by the wild dog.' }
\end{aligned}
$$

In Dholuo, the pronominalized object of a transitive predicate is consistently realized as a suffix/enclitic (17), whereas the pronominalized subject is consistently realized as a prefix/proclitic (18) (The St Joseph's Society, 1921; Omondi, 1982; Tucker, 1994; Okoth-Okombo, 1997; Ochola, 1999).

$$
\begin{aligned}
& \text { (Dòrínà) n-ó-gò-yè/yì/yà. } \\
& \text { Dorina PAST-3s-beat-3s/2s/1s } \\
& \text { 'She (Dorina) beat him/her/it//you/me.' [Adapted from Ochola's (8b)] } \\
& \text { a/i/o-tê' do. } \\
& \text { 3s/2s/1s-cook.PERF } \\
& \text { 'I have cooked.' }
\end{aligned}
$$$$
\text { Dorina PAST-3s-beat-3s/2s/1s }
$$

Additionally, a strong pronoun is illicit without the additional presence of a weak pronoun on the verb. In impersonal passives, whenever the patient is a strong pronoun, the weak pronoun attached to the verb is a suffix/enclitic rather than as a prefix/proclitic. This is shown in (19) (Ochola, 1999, 39).

$$
\begin{aligned}
& \text { ân n-ò-gò-yà (gi Dòrínà). } \\
& \text { I/me PAST-EXPL-beat-1s (by Dorina) } \\
& \text { 'I was beaten (by Dorina).' }
\end{aligned}
$$

(19) is a regular case of fronting of the patient. Obligatory object marking on the verb here makes it visible that the patient is 'foregrounded' (topicalized) rather than promoted to grammatical subject (Keenan and Dryer, 2007). 
In sum, what we have shown so far is that is that in impersonal passives, patients do not behave like regular grammatical subjects, but rather like grammatical objects.

\subsection{On topicalization}

We have seen that the patient can either remain in its canonical postverbal position or appear preverbally. This is illustrated again in (20) and in (21-b).

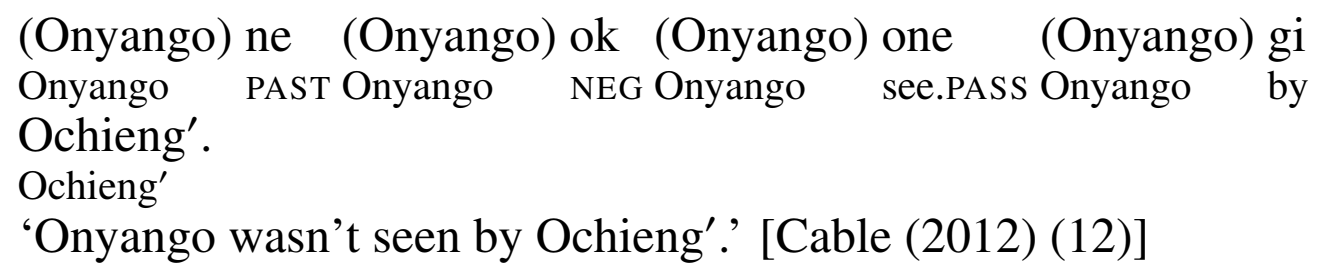

(21) a. bá-alí-ly-a ífy-ákulya (ku mu-mbúlu). sm2-PAST-eat-fv 7-food by 3-wild.dog

'The food was eaten by the wild dog.'

b. Ify-ákulya bá-alí-ly-a (ku mu-mbúlu). 7-food sm2-pst-eat-fv by 3-wild.dog 'The food was eaten by the wild dog.' (Kula and Marten, 2010)

$\mathrm{K} \& \mathrm{M}$ do not elaborate on what determines the position of the patient in Bemba. In Dholuo, its position depends on it being assigned the 'Topic function' (Okoth-Okombo, 1997, 111). Although truth-conditionally equivalent, the examples in (22) are described as having distinct appropriateness conditions.
a. Inego kwach.
kill.PASS.IMPERF leopard
'A leopard is being killed.' [Okoth-Okombo, p112 (78)]
b. Kwach inego.
leopard kill.PASS.IMPERF
'A leopard is being killed.' [Okoth-Okombo, p112 (79)]

(22)a is appropriate as an answer to a question about 'what is taking place', as in (23)a. (22)b preferably answers a question related to 'what is happening to the leopard', as in (23)b.
a. Ango ma timore ka?
what REL happen.IMPERF here
'What is happening here?' [Okoth-Okombo, p112 (80)]
b. Itimo kwach nade?
do.PASS.IMPERF leopard how
'What is being done to the leopard? [Okoth-Okombo, p112 (81)]

We proposed in Hamlaoui and Makasso (2013) and Hamlaoui (2013) that whenever the patient is preverbal, it occupies a clause-internal, argumental, topic po- 
sition. Substantiation of this claim will also come from the two other types of bare-passives discussed in Section 3 and 4. In our view, this position is reminiscent of the German Spec,CP except that it is located in the inflectional domain, hence the possibility for the fronted patient to subject-agree with the verb (see Section 4) and possibly develop into a grammatical subject. In the case of Dholuo, Cable (2012) shows that the position occupied by a fronted object is an A(rgument)-position. ${ }^{4}$ Obviation of Principle C violations, in (24), and tolerance of 'weak crossover', in (25) are considered characteristic of movement to an A-position (we do not go into too much detail here, and refer the interested reader to Cable's paper). These facts, which are consistent with our proposal, are taken as evidence that the preverbal object occupies the regular grammatical subject position by Cable.
a. Ne ok other [japuonj Otieno ${ }_{1}$ ] gi en en $_{2 / * 1}$.
PAST NEG like.PASS [teacher Otieno] by him 'Otieno, ${ }_{1}$ 's teacher is not liked by him $_{2 / * 1}$ ',
b. [Japuonj Otieno $\left.{ }_{1}\right]$ ne ([Japuonj Otieno 1$]$ ) ok ([Japuonj
Otieno $\left._{1}\right]$ ) oher gi en $1 / 2$.
Otieno]) like.PASs by him
'Otieno, 1 's teacher is not liked by him $_{1 / 2}$. [Cable's (25)]

What we see in (24)a is that the pronoun cannot corefer with an expression that it c-commands, in accordance with Principle $\mathrm{C}$ of binding theory. According to Cable, who assumes that the gi-phrase c-commands the postverbal patient, the fact that the pronoun can corefer with the patient whenever the latter is fronted, as in (24)b, suggests that fronted patients occupy an argument position. A similar conclusion can be drawn from (25), with a quantificational expression. The fact that the fronted expression in (25) can bind the pronoun his also suggests that it occupies an A-position (again, see Cable for more details).
a. Oka [wuoi ka wuoi] $]_{1}$ gi guoge $e_{2 / * 1}$.
bite.PASS every.boy
by dog.his
'Every boy ${ }_{1}$ was bitten by his $2 / * 1$ dog.
b. [Wuoi ka wuoi $]_{1}$ oka gi guoge $e_{1 / 2}$. every.boy bite.PASs by dog.his
Every boy ${ }_{1}$ was bitten by his ${ }_{1 / 2}$ dog. [Cable's (29)]

These results go in the same direction as previous accounts of pseudo-passive object-topicalization according to which (i) the object is fronted to a position within the clause (rather than somewhere in the left-periphery of the clause), (ii)

$4 \quad$ Legate (2012) also argues that in the Ahcenese (Malayo-Polynesian, Indonesia) impersonal passive, the fronted object occupies an A-position. Like Cable, she however interprets this fact as an argument in favor of the structural passive analysis of this construction. 
the fronted object is still treated as a core argument of the verb, despite possible resumption (Noonan and Bavin Woock, 1978; Woolford, 1991; Ochola, 1999; Bostoen and Mundeke, 2011).

Just like in Mbuun and Bàsàá (see Section 3), (25)b additionally shows that 'topicalization' of non-referential expressions is also licit in Dholuo. By way of illustration, the left-dislocation of a non-referential expression is illicit in French. See (26) and (27) from de Cat (2007).

(26) *Tout homme, il est mortel. any/every man he is mortal

'Every man is mortal.'

(27) *Chaque potager, il a son robinet. each allotment it has its tap 'Every allotment has its tap.'

In sum, what we have proposed in this section is that there is a type of language in which the grammatical subject must match the thematically highest argument available. Whenever this requirement cannot be fulfilled, most probably due to conflicting information-structural requirements related to topicality (see (1)), what we see in languages like Dholuo and Bemba is that an agentive place-holder is used as the grammatical subject. The patient remains an object, and the logical agent is introduced with a lower thematic/semantic role, typically as a locative or an instrument. By doing so, these languages can simultaneously satisfy the default subject/agent mapping, and have a (full, nominal) agent outside of the Spec,TP position. A side-effect of this matching restriction is a clearer structural split between subjecthood and topicality. A phrase with greater topicality than the preferred grammatical subject can either stay in its canonical object position, or occupy a clause-initial, topic-like, A-position within the inflectional domain. In both cases, the object is however the first nominal argument (linearly) and thus satisfies the constraint in (1).

Let us now turn to zero-coded passive left-dislocation, in which the selected argument with the highest thematic role occupies Spec,TP and an argument with higher topicality is left-dislocated to our Spec,TopP.

\section{Left-dislocation passives}

Just like impersonal passives, Zero-coded passive left-dislocation is found in both Bantu and Nilotic languages. In Lango (Nilotic, Uganda), bare-passive left-dislocation has been discussed in a series of papers (Noonan, 1977; Noonan and Bavin Woock, 1978; Woolford, 1991) as well as in a grammar (Noonan, 1992). What Noonan calls a 'passive-analog', and which is 'created by a rule of NP-fronting', is illustrated in (28) to (30). What we see for instance in (28) 
is that the object 'you', whose canonical position is after the verb, is located at the left-edge of the clause and resumed by an object marker. As noted by Noonan, fronting the object 'advances an NP to sentence initial position' (p128). According to Noonan, resumption is only obligatory for first and second person pronouns and complement of prepositions, as visible in (28) and (29). In contrast, non-human direct objects never display a resumptive pronoun, as illustrated in (30).

$$
\begin{aligned}
& \text { yín dákô òmìyí dyèl. } \\
& \text { you woman 3s.give.perf.2s goat } \\
& \text { 'You were given a goat by the woman.' }
\end{aligned}
$$

(29) án rwòt òmìnò dyàn bòtá.

I king 3s.give.perf cow to.1s

'I was given the cow by the king.'

(30) àpwô àtîn ònènò.

hare child 3s.see.perf

'The hare was seen by the child.'

Bare-passive left-dislocation displays a number of properties that distinguishes it from the type of left-dislocation that has been discussed in many European languages. As shown by the existing literature on Lango bare-passives, the dislocated phrase is syntactically more akin to a grammatical subject than to a hanging topic (see references infra). We will illustrate this subsequently, with data from Bàsàá (Bantu, A43) (Hamlaoui and Makasso, 2013; Hamlaoui and Szendrői, in press).

Before turning to Bantu languages, note that Lango does not have a morphological passive. The correlation between the absence of morphological categories and the use of bare-passive strategies established by Cobbinah and Lüpke (2009) thus holds for this Nilotic language. It also holds for Mbuun (Bantu B87, DRC), whose functional passive left-dislocation has recently been discussed. Bostoen and Mundeke (2011) (henceforth B\&M) show that in this language, which also lacks morphological passive marking, left-dislocating an object is the functional equivalent of a long passive. One of their examples of "functional-passive" left-dislocation is given in (31).

$$
\begin{aligned}
& \text { ba-án taar o-á-(bá-)bol. } \\
& \text { 2-child father SM1-PRES-(OM2-)beat } \\
& \text { 'The children are beaten by father.' }
\end{aligned}
$$

According to $\mathrm{B} \& \mathrm{M}$, this pattern contrasts with what is observed in contrastive left-dislocation, where resumption is obligatory. This is illustrated in (32), in which both types of left-dislocation are at play. 

a. taar o-á-pa nkáb i-koon.
father SM1-PRES-give beggar 5-banana
'Father gives the beggar a banana.'
b. nkáb i-koon taar o-á-(lá-)mó-pa
beggar 5-banana father SM1-PRES-(OM5-)OM1-give
'The beggar, a banana is given to him by father.'
c. i-koon nkáb taar o-á-lá-(mó-)pa
5-banana beggar father SM1-PRES-OM5-(OM1-)give
'The banana, the beggar is given it by father.'

Note however that whenever a speech act participant is involved in passive leftdislocation, resumption is obligatory. This is illustrated in (33) (B\&M, p77).

$$
\begin{aligned}
& \text { mme a-mpúlúús ba-á-mé/N-ley. } \\
& \text { me 2-police SM2-PRES-OM1sg-search } \\
& \text { 'I am wanted/searched by the police.' }
\end{aligned}
$$

Patterns of resumption thus vary both language internally and cross-linguistically, and more research is needed to account for resumption in pseudo-passives.

Importantly to us, zero-coded left-dislocation is not limited to languages that lack passive morphology, suggesting, again, that paucity of morphological categories is not the source of bare-passives. Northern Bàsàa is yet another language that displays this special type of left-dislocation. In contrast to Mbuun and Lango, Bàsàa has a passive extension, which is used in short (neutro) passives, as in (34)b. As shown in (34)c, in this language long passives are ill-formed.
a. síngá ì-ǹ-đgé tólò.
9.cat 9.AGR-PST1-eat 1.mouse
'The cat ate the mouse.'
b. tòlò à-n-dzé- $\beta$ â. 1-mouse 1.AGR-PST1-eat-PASS
'The mouse was eaten.'
c. *tòlò à-ǹ-obé- $\beta$ â nì síngá.
1.mouse 1.AGR-PST1-eat-PASS by 9.cat
'The mouse was eaten by the cat.'

What we call the neutro-passive in (34)b is a structure in which no agent argument is in fact selected by the verb. This is consistent with the fact that an adverb like 'voluntarily' cannot be inserted in this type of sentences, as in (35).

$$
\begin{aligned}
& \text { tòlò à-ǹ-djé- } \beta \text { â } \quad(* \text { nì ǹjèy). } \\
& \text { 1.mouse 1.AGR-PST1-eat-PASS with will } \\
& \text { 'The mouse was (*voluntarily) eaten.' }
\end{aligned}
$$

The grammatical alternative to the long passive in (34)c is given in (36). Just like in Lango and Mbuun, it consists in 'foregrounding' the patient by leftdislocating it. 
In Hamlaoui and Makasso (in press), we argue that just like Lango, Bàsàa is an "indirect role marking language", in that surface positions primarily encode grammatical relations. In both languages, there are few deviations from the basic SVO order. In our view, the fact that the expression of argument structure tends to take the upper hand on the expression of information structure might be the source of bare-passive left-dislocation in these two languages. This hypothesis remains to be tested in Mbuun.

\subsection{Bare-passive vs morphological passive}

Bare-passive left-dislocation is somehow less restricted that the morphological passive as, as shown in (37) and (38), it can target either of the two objects of a ditransitive passive. A similar pattern is observed in Mbuun and Lango, in which bare-passive left-dislocation is not limited to patient arguments (Noonan, p151; B\&M, p77).

$$
\begin{aligned}
& \text { 6-òòngé 6ó-6á-sô sóyól à-ǹ-tí } 1 \text { 6ó ndáp. } \\
& \text { 2-children 2.PRO-2CONN-all 1.grandfather 1.AGR-PST1-give 2.PRO 9.house } \\
& \text { 'All the children, the grandfather gave them a house.' } \\
& \text { (= All the children were given a house by the grandfather) } \\
& \text { ndáp sóyól à-ǹ-tí } \quad \text { jó 6-òòngé 6ó-6á-sô. } \\
& \text { 9.house 1.grandfather 1.AGR-PST1-give 9.PRO 2-children 2.PRO-2CONN-all } \\
& \text { 'A house, the grandfather gave it to all the children.' } \\
& \text { (= A house was given to all the children by the grandfather) }
\end{aligned}
$$

Note however that, just like Lango (Noonan, 1992, 150) (and what seems to be the case in Mbuun too), this type of left-dislocation only targets one argument of the verb at a time, as illustrated in (39).

$$
\begin{aligned}
& \text { *ndáp 6-òòygé 6ó-6á-sô sóyól à-ǹ-tí } \quad \text { 6ó jó. } \\
& \text { 9.house 2-children 2.PRO-2ConN-all 1.grandfather 1.AGR-PST1-give 2.PRO 9.PRO } \\
& \text { 'A house, all the children, the grandfather gave it to them.' }
\end{aligned}
$$

This restriction might indicate that, contrary to the process of left-dislocation found in French, in which several phrases can simultaneously be dislocated, Bàsàá, Mbuun and Lango's left-dislocated arguments occupy a specific (argument) position. An example of (colloquial) French multiple left-dislocation is given in (40). 
(40) Tu comprends Jacqueline, sa mère, la bonne, elle la lui you understand Jacqueline her mother the housekeeper she her to-her refile. gives(familiar)

'You understand, Jacqueline's mother gives her housekeeper to her.' (Gadet 1989:171)

Further differences between Romance/Germanic left-dislocation and pseudopassive left-dislocation are discussed in the following.

\subsection{Bare-passive LD vs LD}

Whereas Romance and Germanic languages can either dislocate phrases to the left or the right of the core-clause, there is no right-hand counterpart to barepassive left-dislocation. In Bàsàá, right-dislocation gives rise to a reading which has not yet been fully investigated, and in which the object's referent is understood as a special, non-representative member of its class (for instance, particularly big).

$$
\begin{aligned}
& \text { síngá ì-ǹ-đ̧é né tòlò. } \\
& \text { 9.cat 9.AGR-PST1-eat 1.PRO 1.mouse } \\
& \text { 'What a mouse the cat ate!' (In colloquial French: 'Il a mangé une de } \\
& \text { ces souris!') }
\end{aligned}
$$

Another trait of bare-passive left-dislocation is that singular quantified expressions and non-specific indefinites can participate in this process.

$$
\begin{aligned}
& \text { hí }{ }^{\downarrow} \text { ý ì ǹ-tómbá nojèe ì-ǹ-nóol jó. } \\
& \text { every 3-sheep 9.lion 9.AGR-PST1-kill 3.PRO } \\
& \text { 'Every sheep, the lion killed it' } \\
& \text { (= Every sheep was killed by the lion) }
\end{aligned}
$$

Bare-passive left-dislocation can take place in clauses with non-root properties, like restrictive-relative clauses, as in (43), whereas this is not possible in French (44).

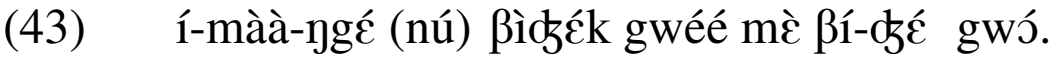
aug-1-child (that) 8.food 8.poss I pst2-eat 8.PRO

'The child whose food I ate it.' (Jenks et al., 2012) (= The child whose food was eaten by me)

(44) *le livre qu'à Marie $_{i}$, Pierre lui $i_{i}$ a donné

The book that-to Marie Pierre to-her has given

'The book that Peter gave to Mary'

Altogether, these properties thus distinguish zero-coded left-dislocation from the Romance or German-type of left-dislocation illustrated from (45) to (48). 
(45) La pluie $_{i}$, ta salade , $_{j}$ elle $_{i}$ lui $_{j}$ fera du bien.

'The rain will do some good to your salade' [French CILD, de Cat $(2007,91)]$

(46) Giorgio $_{i}$, non conosco la ragazza che lui $i_{i}$ vuole sposare.

'I don't know the girl that Giorgio wants to marry.' [Italian HTLD, Cinque $(1983,97)]$

(47) Hans $_{i}$, jeder mag ihn . $_{\text {. }}$

'Everyone likes Hans' [German HTLD, Frey (2005)]

(48) $\mathrm{John}_{i}$, he $_{i}$ never does anything right. [English LD, Downing (1970)]

Despite their disagreement on the exact location of these left-dislocated phrases, researchers generally agree on the fact that they are located outside of the inflectional domain. Existing proposals are illustrated in (49) to (52). The most recent approach, in (52), even places these dislocated phrases in a separate clause (Ott, 2013).

(49) [тр LD-XP [тр ... Resumptive...]] (de Cat, 2007)

(50) [CP Contrastive Topic [CP Topic [IP Subject [Topic Topic [vP ... Resumptive...]]]]] (Cheng and Downing, 2009)

(51) [TopP LD-XP [FocP $O p$ [IP ... Resumptive ...]]] (Cinque, 1983)

(52) $\left[\mathrm{CP} 1 \mathrm{LD}-\mathrm{XP}\right.$ material identical to $\left.\mathrm{CP}_{2}\right]\left[{ }_{\mathrm{CP} 2} \mathrm{Op} \ldots\right.$ Resumptive ...] (Ott, 2013)

This contrasts with what has been proposed for bare-passive left-dislocation. Not much formal work has been done on the topic. Woolford (1991) however proposes that in Lango, the fronted patient occupies Spec,IP (/Spec,TP), while the agent simply stays in $\mathrm{Spec}, \mathrm{VP}(/ \mathrm{Spec}, v \mathrm{P})$. This is illustrated in (53).

\section{[IP $\mathrm{NP}_{i}\left[\mathrm{vP} \mathrm{NP} \mathrm{V} t_{i} /\right.$ pronoun $\left.\left._{i}\right]\right]$}

Her analysis, which accounts for the observations made in Lango, Mbuun and Bàsàa that the fronted patient is akin to a second subject, is however problematic in at least two ways. First (from a purely theory-internal perspective), it violates Relativized Minimality (Rizzi, 1990): what would motivate the movement of the patient to Spec,TP over the agent? Second, in a Bantu language like Bàsàá, subject-verb agreement systematically occurs in TP, and one would need to explain why it takes place in $v \mathrm{P}$ in bare-passive left-dislocation.

Instead, we propose the structure in (54) (Hamlaoui and Makasso, 2013; Hamlaoui and Szendröi, in press), in which both agent and verb occupy their regular position under TP, and the topical patient occupies a clause-internal, argumental, topic position. This position is the one that is occupied by fronted 
patients in impersonal passives, and we will argue in Section 3.3. that it is the one occupied by fronted objects in OVS bare passive sentences in Kinyarwanda/Kirundi.

$$
\text { [CP … [TорР } \left.\left.\mathbf{D P}_{i}\left[{ }_{\mathrm{TP}} \mathbf{D P}_{j} \mathbf{V}_{k}\left[{ }_{\mathrm{vP}} t_{j} \mathrm{~V}_{k}\left[\mathrm{vP} \mathrm{V}_{k} \mathrm{t}_{i} \text { /pronoun }_{i}\right]\right]\right]\right]\right]
$$

Again, we do not address here the issue of resumption, and how the object can sometimes be doubled. We leave this issue open for future research.

In sum, if we are on the right track, Dholuo, Bemba, Lango, Mbuun and Bàsàá are similar in that they need for the most topical argument to come first (linearly). Their strong requirement for matching the highest thematic argument available with the grammatical subject (Spec,TP) prevents them from doing so by realizing the non-agent as the grammatical subject. Instead, Lango, Mbuun and Bàsàa simply locate the topical object in a syntactically higher (argument) position. They operate a clear split between topicality (being the subject of the predication) and subjecthood (being in Spec,TP).

\section{Reversal passives}

Subject-object reversal passives are our third and last type of bare-passive. They have been extensively discussed in Kinyarwanda/Kirundi (a.o. Kimenyi, 1980, 1988; Morimoto, 2000; Henderson, 2006, 2011). To the best of our knowledge, this strategy has not been observed in Western Nilotic.

The Kinyarwanda/Kirundi-type of OVS, in which the object controls subject agreement on the verb is illustrated in (55) for Kinyarwanda, and in (56) for Kanyok. ${ }^{5}$

igi-tabo ki-som-a umu-huûngu.

7-book SM7-read-ASP 1-boy

'The book is being read by the boy.' (Kimenyi, 1980, 192)

(56) mi-saany yì-dyààdy ba-tùw.

4-fish SM4-eat 2-fisherwoman

'The fish is eaten by the fisherwomen.' (Bostoen and Mundeke, 2011, p165, from p.c. with Timothee Mukash-Kalel)

As the existing literature on this type of OVS shows, the preverbal object and the postverbal subject retain their respective object and subject properties: "NPs advanced to subject by the [Subject-Object] reversal rule do not acquire the properties of basic subjects, such as raising, deletion under identity, and hainsertion" (Kimenyi $(1980,145)$ from Morimoto $(2006,166))$. The only subjectlike properties of the object are its linearly preverbal location and its control over

5 We do not discuss Bantu OVS in which subject-agreement is controlled by the postverbal subject. We refer the interested reader to van der Wal (2012). An extension of some of our proposals to Matengo (N13, Tanzania) can already be found in van der Wal (2014). 
subject-agreement. It cannot be left-out and represented by a subject marker on the verb, as can be done with regular subjects. In addition, the postverbal agent can neither be left-out, nor substituted by an object marker on the verb.

Several proposals have been made to account for this type of OVS (see Marten, this volume). We will mention only two of them here. Concentrating on the fact that the postverbal subject is interpreted as focused, Ndayiragije (1999) proposes that, in OVS structures, the subject is moved from Spec, $v \mathrm{P}$ to the specifier of a Focus projection (FocP), thus freeing the non-agent to move to Spec,TP and avoiding a violation of relativized minimality. It is not however entirely clear to us how this proposal accounts for the fact that a preverbal object does not behave like a regular subject in Spec,TP. Morimoto (2000, 2006), in contrast, concentrates on the topicality of the preverbal object. In a nutshell, she proposes that Kinyarwanda/Kirundi is a language in which the verb subject-agrees with a topic and is thus a(n internal) topic-marker rather than a subject-marker. If there are indeed languages in which verbs agree with the most topical element in the clause (rather than with the one realizing a certain case or the highest thematic role), Morimoto's account predicts that we should find languages in which this happens independently of the position of this element (just like, cross-linguistically, subject-agreement based on case/thematic role happens independently of the position of the grammatical subject (i.e. pre or postverbal)). To the best of our knowledge, there are no languages in which a verb identifies the most topical phrase around and subject-agrees with it no matter where it is located. What we see in Kinyarwanda/Kirundi is that "topicagreement" is dependent on the position of the most topical phrase. This phrase must immediately precede the verb, and we believe that it must be in a SpecHead configuration with it.

We propose that in the present type of OVS structure, the agent is a regular subject, that occupies the Spec,TP position. By doing so, it fulfills the requirement that the selected argument with the highest thematic role realize the grammatical subject. This accounts for the non-object properties of this type of postverbal subject. The OVS word order is derived by moving the topical object and the verb to the (inflectional-domain internal) TopP. Contrary to the common view, the postverbal subject here neither stays low (in $v \mathrm{P} / \mathrm{VP}$ ) nor moves to the right of the verb. Rather, the verb and the object move to the left of the subject. This proposal is illustrated in (57).

$$
\left.\left.\left.\left[\mathrm{CP} \cdots\left[{ }_{\mathrm{TopP}} \mathbf{D P}_{i} \mathbf{V}_{k}\left[\mathrm{TP}_{\mathrm{TP}} \mathbf{D P} \mathbf{V}_{j}<\mathrm{V}\right\rangle_{k}\left[{ }_{\mathrm{vP}} t_{j}<\mathrm{V}\right\rangle_{k}[\mathrm{vP}<\mathrm{V}\rangle_{k} t_{i}\right]\right]\right]\right]\right]
$$

As argued by Baker (2008), asymmetric c-command is a strong requirement for subject-agreement in Bantu languages, compared to Indo-European languages, in which subject agreement normally takes place with the argument carrying the subject case/thematic role, no matter its syntactic location. Under the present 
view, what we see in Kinyarwanda is an application of this configuration-based agreement: the verb simply agrees with the argument with which it ends up being in a Spec-Head configuration, even if it is not the highest thematic role available. ${ }^{6}$ Additionally, and in contrast with (non-passive-related) OVS structures, observed for instance in V2 languages like German, in which $\mathrm{O}$ and V sit in the $\mathrm{CP}$ domain and do not subject-agree, what is observed in Kinyarwanda suggests that $\mathrm{O}$ and $\mathrm{V}$ sit within the inflectional domain. If we are on the right track, the Kinyarwanda-type of OVS illustrates Kula \& Marten's claim that "subject and object marking cannot [always] be taken as a reliable indication of syntactic subject and object status" (p31).

The relation between the OSV and OVS zero-coded passives was already noted by Bostoen and Mundeke (2011). In our approach, the difference between Bantu languages like Bàsàá and Kinyarwanda/Kirundi is related to how high the verb can move, rather than to the nature of agreement (contra Morimoto (2000, 2006)). The main difference between OSV (Section 3) and OVS bare-passives is thus the height of the verb.

In Kinyarwanda/Kirundi, a motivation for the movement of the verb to Top can be found in the need for aligning focused phrases with the right edge of the clause. No such need is found in Bàsàá, for instance (Hamlaoui and Makasso, in press). As already noted in Hamlaoui and Makasso (2013), a number of facts reported by Kimenyi $(1980,1988)$ and Ndayiragije (1999) indeed suggest that in Kinyarwanda/Kirundi, a focused phrase must align with the right-edge of a clause. By way of illustration, in Kinyarwanda a verb can have up to three prepositionless objects. This is shown in (58). According to Kimenyi, "there is free word order of objects except that it is the new information which always comes last."
Abagabo ba-ra-so-baanur-ir-a abagóre ábáana ibibazo. men they-TNS-explain-APPL-ASP women children questions
'The men are explaining the questions to the children for the women'. (Kimenyi, 1988, 356)

Examples (59) and (60) (from Ndayiragije, 1999) further illustrate the relative freedom of word order in the postverbal domain, with the need for the focused phrase to be rightmost within the clause.

$$
\begin{aligned}
& \text { Yohani a-á-oógeje néezá imiduga. } \\
& \text { John sm1-PST-wash.PERF well cars } \\
& \text { 'John washed CARS well.' }
\end{aligned}
$$

As already mentioned in Hamlaoui and Makasso (2013), our configuration-based agreement proposal makes the prediction that postverbal subject-agreement should be highly restricted/impossible in the Kinyarwanda/Kirundi-type of languages. 


Yohani a-á-oógeje imiduga néezá.
John SM1-PST-wash.PERF cars well
'John washed cars WELL.'

As argued in Hamlaoui (2009), cleft-sentences of the type illustrated in (61) can also fulfill this requirement.

\author{
Ni abâna ba-á-nyôye amatá. \\ be children SM2-PST-drink.PERF milk \\ 'It was CHILDREN who drank milk.' Kirundi (Ndayiragije, 1999, 407)
}

If we are on the right track, the OVS bare-passive structure is an optimal strategy to align a subject with the right edge of the clause and simultaneously realize the default mapping between Spec,TP and the selected argument with the highest thematic role.

\title{
5 Concluding remarks
}

In this note, we concentrated on three bare-passive structures found in Bantu (Bàsàá, Bemba and Kinyarwanda) and Western Nilotic (Dholuo and Lango). We argued that impersonal passives, zero-coded passive left-dislocations and so-called "subject-object reversal" passives constitute an optimal strategy to change prominence relations between arguments, in languages that strongly hold to the default mapping between the selected argument with the highest thematic role and the grammatical subject (i.e. Spec,TP). The languages discussed in the present paper differ in how they satisfy this mapping. Dholuo and Bemba resort to an agentive place-holder (an indefinite subject marker, whose exact syntactic location remains to be investigated) and turn the logical agent into a lower thematic role (e.g. instrument, locative). By doing so, they can realize the logical agent in a lower syntactic position. Bàsàá, Mbuun, Lango and Kinyarwanda/Kirundi, in contrast, locate the nominal phrase with the highest thematic role under Spec,TP, and locate the most topical argument in a higher argument position within the inflectional domain. From an information-structural perspective, these bare-passive strategies primarily allow to place the argument with the highest topicality first (linearly). Depending on the language, impersonal passives and OVS passives can additionally allow to align a focused agent with the right edge of the clause. In Hamlaoui and Makasso (2013), we proposed the "mini-typology" of transitive passive constructions in Figure 1, in which we also included long passive sentences common in French, English or in Bantu languages like Swahili or Sotho/Tswana, for instance.

Whereas all types of transitive passives represented pragmatically demote agents and pragmatically promote a non-agent, only English/French long passives and Kinyarwanda/Kirundi OVS grammatically promote the non-agent by having it subject-agree with the verb. The grammatical demotion of the agent 
is only found in English/French long passives and (partially) in Dholuo/Bemba impersonal passives, as OVS and OSV passives locate the agent in its regular grammatical subject position (Spec,TP). On the syntactic level, grammatical demotion or promotion is thus dependent on the type of transitive passive one considers.

\begin{tabular}{|c|c|c|}
\hline Transitive passive & $\begin{array}{c}\text { Grammatical Promotion } \\
\text { of Object }\end{array}$ & $\begin{array}{c}\text { Grammatical Demotion } \\
\text { of Subject }\end{array}$ \\
\hline $\begin{array}{c}\text { O-V by S } \\
\text { (English, French) }\end{array}$ & + & + \\
\hline $\begin{array}{c}\text { O expl-V by S } \\
\text { expl-V O by S } \\
\text { (Bemba) }\end{array}$ & - & + \\
\hline $\begin{array}{c}\text { O-VS } \\
\text { (Kinyarwanda) }\end{array}$ & + & - \\
\hline $\begin{array}{c}\text { OS-V (pro) } \\
\text { (Bàsàa, Mbuun) }\end{array}$ & - & - \\
\hline
\end{tabular}

Figure 1 : Mini-typology Transitive Passive (Hamlaoui and Makasso, 2013)

Our work on bare-passives is still in progress, and as the attentive reader will have noted, a number of issues were left open for future research. To be continued...

\section{References}

Baker, Mark. (2008). The syntax of agreement and concord. Cambridge University Press.

Bostoen, Koen, and Leon Mundeke. (2011). Passiveness and inversion in Mbuun (Bantu B87, DRC). Studies in Language 35 (1): 72-111.

Cable, Seth. (2012). The optionality of movement and EPP in Dholuo. Natural Language and Linguistic Theory 30: 651-697.

Cheng, Lisa Lai-Shen, and Laura J Downing. (2009). Against FocusP: arguments from Zulu. In Proceedings of the UCL workshop on information structure, eds. Ivona Kucerova and Ad Neeleman. Cambridge University Press.

Chomsky, Noam. (1981). Principles and parameters in syntactic theory. In Explanation in linguistics, 32-75. London: Longman.

Cinque, Guglielmo. (1983). Connectedness in sentence, discourse and text, 7-41. Tilburg: KUB.

Cobbinah, Alexander, and Friederike Lüpke. (2009). No cut to fit - zero coded passives in African languages. In Proceedings of the 6th World Congress of African Linguistics, eds. M Brenzinger and A M Fehn, 153-165. Cologne: Köppe.

de Cat, Cécile. (2007). French dislocation: Interpretation, Syntax, Acquisition. OUP.

Downing, Bruce T. (1970). Syntactic structure and phonological phrasing in english. PhD diss, University of Texas at Austin.

Frajzyingier, Zygmunt. (1982). Indefinite agent, passive and impersonal passive: a functional study. Lingua 58: 267-290. 
Frey, Werner. (2005). Pragmatic properties of certain German and English left peripheral constructions. Linguistics 43: 89-129.

Gadet, Françoise. (1989). Le français ordinaire. Paris: Armand Colin.

Givón, Talmy. (1979). On understanding grammar. New York: Academic Press.

Gundel, Jeanette. (1988). Universals of topic-comment structure. In Studies in syntactic typology, eds. M Hammond, E A Moravcsik, and Worth J R, 209-239. John Benjamins.

Hamlaoui, Fatima. (2009). La focalisation à l'interface de la syntaxe et de la phonologie: le cas du français dans une perspective typologique. PhD diss, Université Paris III Sorbonne Nouvelle.

Hamlaoui, Fatima. (2013). Dholuo (pseudo-)passive and the parametrization of EPP. Ms. ZAS, under revision.

Hamlaoui, Fatima, and Emmanuel-Moselly Makasso. (2013). Bàsàa object left-dislocation, topicalization and the syntax-phonology mapping of Intonation Phrases. Paper presented at the 5th international conference on Bantu languages. Ms. ZAS.

Hamlaoui, Fatima, and Emmanuel-Moselly Makasso. (in press). Focus marking and the unavailability of inversion structures in Bàsàá (A43). Lingua.

Hamlaoui, Fatima, and Kriszta Szendrói. (in press). A flexible approach to the syntaxphonology mapping of intonational phrases. Phonology.

Haspelmath, Martin. (1990). The grammaticalization of passive morphology. Studies in Language 14: 25-72.

Henderson, Brent. (2006). The syntax and typology of Bantu relative clauses. PhD diss, Unversitiy of Illinois at Urbana-Champaign.

Henderson, Brent. (2011). Agreement, locality, and OVS in Bantu. Lingua 121 (5): 742-753.

Jenks, Peter, Emmanuel-Moselly Makasso, and Larry M Hyman. (2012). Accessibility and demonstrative operators in Bassá relative clauses. To appear in a volume on relative clauses in the languages of Cameroon.

Kawasha, Boniface. (2007). Passivization in Lunda. Journal of African Languages and Linguistics 28: 37-56.

Keenan, Edward, and Matthew Dryer. (2007). Clause structure, language typology and syntactic description, Vol. 1, 325-361. Cambridge: CUP.

Kimenyi, Alexandre. (1980). A relational grammar of Kinyarwanda. University of California Press.

Kimenyi, Alexandre. (1988). Passives in Kinyarwanda. In Passive and voice, ed. Masayoshi Shibatani, 355-386. Amsterdam: John Benjamins.

Kula, Nancy, and Lutz Marten. (2010). Argument structure and agency in Bemba passives. In Bantu languages: Analyses, description and theory, eds. Karsten Legère and Christina Thornell, 115-130. Cologne: Rüdiger Köppe.

Legate, Julie Anne. (2012). Subjects in Acehnese and the nature of the passive. Language 88 (3) 495-525. 
Morimoto, Yukiko. (2000). Discourse configurationality in Bantu morphosyntax. PhD diss, Stanford University, CA.

Morimoto, Yukiko. (2006). Agreement properties and word order in comparative Bantu. ZASPiL 43: $161-187$.

Ndayiragije, Juvénal. (1999). Checking economy. Linguistic Inquiry 30: 399-444.

Noonan, Michael. (1977). On subjects and topics. In Proceedings of the 3rd annual meeting of the berkeley linguistics society, 372-385.

Noonan, Michael. (1992). A grammar of Lango. Walter de Gruyter.

Noonan, Michael, and Edith Bavin Woock. (1978). The passive analog in Lango. In Proceedings of the 4th annual meeting of the Berkeley Linguistics Society, 128-139.

Ochola, Eunita D A. (1999). Is there a passive in Dholuo? Studies in African Linguistics 28 (1): $31-48$.

Okoth-Okombo, Duncan. (1997). A functional grammar of Dholuo. Köln: Rüdiger Köppe Verlag.

Omondi, Lucia Ndong'a. (1982). The major syntactic structures of Dholuo. Berlin: Dietrich Riemer Verlag.

Ott, Dennis. (2013). Connectivity in left-dislcoation and the composition of the left-periphery. Manuscript University of Groningen.

Prince, Alan, and Paul Smolensky. (2004). Optimality Theory: Constraints Interaction in Generative Grammar. Oxford: Blackwell.

Rizzi, Luigi. (1990). Relativized Minimality. MIT Press.

Schadeberg, Thilo. (2003). Derivation. In The Bantu languages, 71-89. London: Routledge.

Shibatani, Masayoshi. (1988). Introduction. In Passive and voice, 1-8. John Benjamins.

Siewierska, Anna. (2010). From third plural to passive: incipient, emergent and established passives. Diachronica: International Journal for Historical Linguistics 27 (1): 73-109.

The St Joseph's Society. (1921). A handbook of the Kavirondo language. Nairobi: Caxton Printing and Publishing Works.

Tucker, Archibald N. (1994). A grammar of Kenya Luo (Dholuo). Köln: Rüdiger Köppe Verlag. van der Wal, Jenneke. (2012). Subject agreement and the EPP in Bantu agreeing inversion. In Cambridge occasional papers in linguistics 6, 201-236.

van der Wal, Jenneke. (2014). A note on the (non-existing) passive in Matengo. To appear in Linguistique et Langues Africaines (LLACAN).

Woolford, Ellen. (1991). Two subject positions in Lango. In Proceedings of the 17th annual meeting of the Berkeley Linguistics Society, 231-243.

Zerbian, Sabine. (2007). Subject/object-asymmetry in Northern Sotho. In Information Structure and the Architecture of Grammar: A Typological Perspective, eds. Kerstin Schwabe and Susanne Winkler, 323-346. Amsterdam: John Benjamins. 